\title{
PELAKSANAAN ALIH TEKNOLOGI PADA INDUSTRI TEKSTIL TERPADU ( INTEGRATED TEXTILE MILLS) PT.PRIMATEXCO INDONESIA DI KABUPATEN BATANG JAWA TENGAH
}

\author{
Siti Zulaekhah, SH.
}

\begin{abstract}
ABSTRAK
Industri tekstil di Indonesia merupakan pensuplai kebutuhan sandang dalam negeri dan dipilih sebagai salah satu fondasi pembangunan disamping sektor pangan. PT. Primatexco adalah salah satu pelopor industri tekstil di Indonesia yang berstatus sebagai PMA-Joint Venture Indonesia-Jepang. Bidang kegiatan usaha perusahaan tersebut adalah industri tekstil terpadu (Integrated Textile Mills). Bidang usaha yang bersifat terpadu menunjukkan bahwa proses produksi di Primatexco sangat sarat dengan teknologi. Oleh karena itu, penulisan penelitian ini berjudul "PELAKSANAAN ALIH TEKNOLOGI PADA INDUSTRI TEKSTIL TERPADU (INTEGRATED TEXTILE MILLS) PT. PRIMATEXCO INDONESIA DI KABUPATEN BATANG JAWA TENGAH."

Permasalahan dalam penelitian ini meliputi ; bagaimana pelaksanaan alih teknologi di PT. Primatexco Indonesia, hambatan-hambatan apa yang dihadapi dan bagaimana upaya-upaya untuk mengatasi hambatan tersebut. Penelitian ini bertujuan untuk menganalisis pelaksanaan alih teknologi di PT. Primatexco Indonesia, menganalisis hambatan-hambatan yang terjadi dalam proses alih teknologi serta menganalisis upaya-upaya yang dilakukan untuk mengatasi hambatan-hambatan tersebut.

Metode Pendekatan penelitian ini adalah Yuridis-Empiris, yakni penelitian dilakukan terhadap data primer terlebih dahulu dan kemudian menganalisis data sekunder. Data primer diperoleh melalui wawancara dengan para pimpinan PT. Primatexco Indonesia serta pihak-pihak yang terlibat langsung dalam proses alih teknologi di perusahaan tersebut. Analisis data dilakukan secara kuantitatif dan kualitatif.

Penelitian ini menghasilkan beberapa kesimpuan : Pertama, di PT. Primatexco telah terjadi alih teknologi dalam bentuk transfer of technical know-how, transfer of manufacturing know-how and transfer of management know-how. Hambatanhambatan dalam penelitian ini adalah kerancuan aturan tentang alih teknologi melalui Joint Venture. Adanya klausul kontrak/perjanjian yang mengharuskan pengiriman mesin melalui Sojitz Corporation, hal ini mengakibatkan praktek terselubung, yakni penggunaan teknologi yang obsolete. Hambatan teknis berupa permasalahan bahasa, dimana kegiatan alih teknologi menggunakan bahasa campuran Inggris-Jepang. Ketergantungan Indonesia pada Jepang karena sektor keuangan dalam kegiatan importasi mesin serta pengadministrasian transasksi LC
\end{abstract}


dikendalikan oleh Jepang. Hal ini telah mengunci Indonesia untuk tidak memiliki pilihan lain, selain tetap tergantung pada teknologi Jepang.

Kata Kunci : Industri Tekstil, PT. Primatexco Indonesia, dan Alih teknologi

\section{A. PENDAHULUAN}

1. Latar Belakang

Sejak awal berdirinya negara Indonesia, fondasi pembangunan yang dipilih oleh para pendiri negeri ini adalah pembangunan pada bidang sandang dan pangan dan bukan industri berat seperti yang dilakukan oleh beberapa negara lain. Pemilihan dua bidang tersebut didasarkan atas fakta belum terpenuhinya kebutuhan-kebutuhan dasar yang menyangkut hajat sebagian besar masyarakat Indonesia. Dua bidang tersebut merupakan landasan dasar yang menjadi pedoman pembangunan pada bidang-bidang yang lain.

Program pembangunan yang dicanangkan oleh Pemerintahan yang pertama sebagaimana tercermin dalam tugas pokok Kabinet Ampera ${ }^{1}$ adalah stabilitas politik dan stabilitas ekonomi dengan program pokok antara lain memperbaiki perikehidupan rakyat terutama di bidang sandang dan pangan dengan cara memprioritaskan produksi bidang-bidang tersebut. Menurut Rochmat Soemitro ${ }^{2}$, basis pembangunan yang dipilih oleh Indonesia adalah menempatkan sandang dan pangan pada prioritas pertama dan dalam masa sekurang-kurangnya 3 tahun setelah kebutuhan sandang pangan dapat dicukupi secara layak akan dimulai dengan usaha-usaha lainnya. Rencana

\footnotetext{
${ }^{1}$ Nugroho Notosusanto, Sejarah Nasional Indonesia3, Cetakan ke-3 (Jakarta: DepDikBud, 1991), hal.228

2 Rochmat Soemitro, Pengantar Ekonomi dan Ekonomi Pancasila, Cetakan VIII(Jakarta-Bandung : Eresco, 1983), hal.180
} 
Pembangunan Lima Tahun (REPELITA) pertama ${ }^{3}$ yang dicanangkan pada tahun 1969-1974 pun menempatkan program pemenuhan kebutuhan sandang-pangan sebagai prioritas yang penting yang kemudian diikuti dengan program-program yang lain seperti perbaikan prasarana, perumahan rakyat, perluasan lapangan kerja serta kesejahteraan rohani. Bahkan dalam REPELITA II pun salah satu butir pembangunan ekonomi nasional masih terfokus pada permasalahan pemenuhan kebutuhan pangan yang dilakukan dengan jalan melipatgandakan produksi sandang, pangan, dan obat-obatan, dan kebutuhan pokok masyarakat.

Untuk menopang terpenuhinya kebutuhan dalam bidang sandang, pemerintah secara terus menerus memberi kesempatan seluas-luasnya kepada pengusaha nasional untuk mendirikan pabrik-pabrik tekstil. Disamping berorientasi pada pemenuhan kebutuhan sandang secara nasional, pada awalnya pendirian pabrik-pabrik juga dimaksudkan untuk menyerap tenaga kerja dalam negeri sebagaimana tercantum dalam Pelita I dimana pembangunan industri berorientasi pada pembangunan industri padat karya. Karena masih berorientasi pada pemenuhan kebutuhan dalam negeri, maka penekanan utama pada proses produksi adalah pada target kuantitas produk. Namun, akibat dari adanya tekanan penduduk yang terus menerus, proses pengolahan tekstil membutuhkan faktor kecepatan tenaga mesin yang tidak hanya memenuhi syarat kuantitas tetapi juga kualitas hasil produksi.

Dalam rangka memenuhi tuntutan tersebut, pemerintah melalui Surat Keputusan Menteri Perindustrian (MENPERIN) No. 41/M/SK/3/1979 membentuk Balai Penelitian dan Pengembangan Industri Tekstil (Balai Besar Tekstil). Salah satu fungsi lembaga tersebut adalah melaksanakan penelitian dan pengembangan bahan baku, proses, peralatan, hasil produksi, dan pencegahan polusi dalam lingkungan industri tekstil. Lembaga penelitian khusus di bidang tekstil tersebut terus melakukan trial and error ${ }^{4}$ yaitu secara

\footnotetext{
${ }^{3}$ Setneg, 30 tahun Indonesia Merdeka 1965-1973, Cetakan ke-7 (Jakarta : PT. Lamtoro Gung Persada, 1986), hal.197

${ }^{4}$ Trial and error adalah cara mengatasi masalah dengan membuat percobaan-percobaan sampai kesalahan dapat diatasi ; penyelidikan melalui berbagai metode atau cara. Lihat Peter Salim,
} 
terus menerus melakukan ujicoba dengan metode-metode tertentu dengan harapan ditemukannya teknologi-teknologi alternatif dalam rangka memecahkan masalah dalam bidang sandang, terutama tekstil. Namun, trial and error tersebut ternyata memakan waktu yang sangat lama, tenaga yang banyak, dana yang sangat besar serta tingginya kemungkinan kegagalan.

Kegagalan metoda trial and error dalam memecahkan permasalahan teknologi tekstil masih belum bisa menjawab persoalan tersebut. Hal itu terbukti dalam periode 1970 hingga tahun 1985 (6 tahun setelah penerbitan Kep MENPERIN) dengan tingkat pertumbuhan industri tekstil yang sangat lamban serba terbatas dan hanya memenuhi pasar domestik (substitusi impor) dengan segmen pasar menengah rendah. ${ }^{5}$

Tingginya tingkat kegagalan trial and error menjadi alasan yang sangat kuat untuk mendapatkan teknologi dengan cara yang cepat dan pasti. Atas dasar tuntutan tersebut, maka sebenarnya telah tersedia sarana perolehan teknologi yakni melalui mekanisme alih teknologi.

PT. Primatexco Indonesia adalah pelopor perusahaan tekstil nasional yang didirikan pada tahun 1970. PT. Primatexco Indonesia merupakan perusahaan Penanaman Modal Asing ( PMA) dengan cara kerjasama dalam bentuk Jonit Venture antara Indonesia dengan Jepang.

Berdasarkan uraian tersebut, maka penelitian ini sangat penting dilakukan untuk menelaah dan menganalisis bagaimana pelaksanaan alih teknologi pada industri pemintalan tekstil terpadu (Integrated Textile Mills) yang sangat padat teknologi tersebut. Untuk menjawab permasalahan tersebut, kami melakukan penelitian dengan judul :"PELAKSANAAN ALIH TEKNOLOGI PADA INDUSTRI TEKSTIL TERPADU ( INTEGRATED TEXTILE MILLS ) PT. PRIMATEXCO INDONESIA DI KABUPATEN BATANG JAWA TENGAH."

Advanced English-Indonesia Dictionary, Edisi kelima (Jakarta : Modern English Press, 2001), hal. 906

${ }^{5}$ http://www.egypsi.wordpress.com, Industri Tekstil dan Produksi Tekstil di Indoensia, diakses pada tanggal 20 Maret 2009. 
2. Permasalahan

a. Bagaimanakah pelaksanaan alih teknologi pada PT. Primatexco Indonesia ?

b. Hambatan-hambatan apa yang dihadapi oleh PT. Primatexco Indonesia dalam pelaksanaan alih teknologi ?

c. Bagaimana upaya-upaya PT. Primatexco Indonesia dalam mengatasi hambatan-hambatan dalam pelaksanaan alih teknologi tersebut?

3. Tujuan Penelitian dan Kontribusi Penelitian

a. Tujuan

1). Untuk menjelaskan dan menganalisis pelaksanaan alih teknologi di PT.Primatexco Indonesia.

2). Untuk menjelaskan dan menganalisis hambatan-hambatan yang dihadapi oleh PT. Primatexco Indonesia dalam pelaksanaan alih teknologi.

3). Untuk menjelaskan dan menganalisis upaya-upaya yang dilakukan oleh PT. Primatexco Indonesia dalam mengatasi hambatan-hambatan dalam pelaksanaan alih teknologi

b. Kontribusi

1). Kontribusi Teoritis

Sebagai sumbangan terhadap pengembangan IImu Hukum khususnya dalam bidang Alih Teknologi.

2). Kontribusi Praktis

Sebagaisumbangan terhadap pengambilan keputusan, baik Pemerintah tentang kebijakan dalam bidang Alih Teknologi maupun PT atau Badan Usaha lainnya yang menyelenggarakan kegiatan alih teknologi 


\section{Tinjauan Pustaka}

a. Asal-usul dan Sejarah Perkembangan Teknologi

Sepanjang sejarah kehidupan manusia hingga saat ini, teknologi telah menjadi kekuatan yang sangat besar terhadap perkembangan peradaban. Teknologi, seperti halnya bahasa, ritual-ritual masyarakat tertentu, nilainilai, perdagangan, dan seni-seni adalah bagian intrinsik dari sitem budaya. Semuanya membentuk dan merefleksikan sistem-sistem nilai.

Teknik-teknik/cara-cara manusia dalam membuat/membentuk alat-alat merupakan bukti yang paling penting dari awal kebudayaan manusia. ${ }^{6}$ Pusat data dari National Academy of Engineering menyebutkan ${ }^{7}$, sepanjang sejarah manusia, teknologi berhubungan erat dengan wilayah kerja ahli-ahli pembuat kerajinan tangan yang mewarisi keahlian dari generasi ke generasi yang secara bertahap mengembangkan desaindesain, meningkatkan teknik-teknik dan bahan-bahan untuk alat yang baru.

b. Keterkaitan antara Ilmu Pengetahuan dengan Teknologi IImu dasar (ilmu pengetahuan) dan ilmu terapan (teknologi) merupakan dua sisi dari satu mata uang yang sudah lama diketahui. ${ }^{8}$ Hubungan antara ilmu pengetahuan dan teknologi tercermin dalam bagaimana manusia mengatasi problema hidup. Proses perekayasaan dalam rangka mengatasi problema hidup manusia tersebut tidak pernah

\footnotetext{
${ }^{6}$ http : //www.project2061.org/publication/Sfaa/online/chap3.htm., The Nature of Technology, diakses pada tanggal 23 Februari 2009

${ }^{7}$ http : //www.nae.edu/nae/techlithome.nfs/weblinks/kgrg_55RMA?open document, The Nature of Technology, diakses pada tanggal 23 Februari

${ }^{8}$ Henry Margenau, et all, Op.Cit, hal.146
} 
lepas dari keberadaan ilmu pengetahuan dan teknologi. Menurut web site TOP :

"...engineering, the systematic application of scientific knowledge in developing and applying technology has grow in a craft to science itself. Scientific knowledge provides a means estimating what the behavior of things will be even before we make them or observe them. Moreover, science suggests new kinds of behavior that had not even been imagined before and so leads a new technologies. Engineers use knowledge of science and technology, together with strategies of design, to solve practical problems."

c. Teori-teori Tentang Teknologi

1). Teori teknologi menurut Andrew Feenberg

Feenberg membagi teknologi kedalam tiga teori besar, yakni Instrumental theory, substantive theori, dan the crithical theory of technology. ${ }^{9}$

(a). Instrumental Theory

Teori ini merupakan teori yang paling banyak diterima. Teori ini berdasar pada pendapat umum bahwa teknologi-teknologi adalah alat-alat yang selalu siap melayani tujuan-tujuan dari para pemakainya.

(b). Substantive Theory

Teori substantif, sebagaimana yang sudah sangat dikenal melalui tulisan Jacques Ellul dan Martin Heidegger, berargumentasi bahwa teknologi menggambarkan tipe-tipe baru sistem budaya yang menyusun ulang atas kesluruhan dunia sosial sebagai satu kesatuan kontrol objek.

(c). The Critical Theory of Technology

${ }^{9}$ http://www-rohan.sds2.edu/faculty/feenberg/CRITISM2.HTM, The Theory of Technology, diakses pada tanggal 9 Februari 2009 
Menurut teori ini, sebenarnya yang menjadi pangkal isu bukanlah teknologi dan kemajuan semata-mata, akan tetapi banyaknya keragaman kemungkinan-teknologi dan perkembangan-perkembangan yang terjadi karenanya yang harus kita pilih.

2). Technological Gap Theory menurut Posner

Posner menganalisis pengaruh teknologi terhadap tingkat kompetisi suatu korporasi. Menurut Posner, teknologi bagi suatu korporasi merupakan unsur yang paling fundamental dalam kaitannya dengan kegiatan usaha yang kompetitif.

3). Neoclassical Growth Theory dan Endegenous Growth Theory

(a). Neoclassical Growth Theory

Menurut teori ini, teknologi sebagai, baik sifat penerapannya yang universal maupun perbedaan-perpedaan dalam penguasaannya merupakan ketimpangan dalam penguasaan objek fisik seperti adanya gedung-gedung pabrik dan jalan-jalan raksasa. Dengan demikian, pandangan ini cenderung melihat teknologi dari aspek fisiknya semata (technological physic).

(b). Endegenous Growth Theory

Jika teori yang pertama lebih menekankan pada ketimpangan penguasaan fisik sebagai sarana perkembangan teknologi, endogenous growth theory berpandangan bahwa ketimpanganketimpangan dalam menggagas ide dan dalam keterbatasan kemampuan negara-negara berkembang untuk menyerap pengetahuan baru merupakan alasan-alasan utama tentang terjadinya kemiskinan. 
d. Konvensi-konvensi Internasional dalam bidang teknologi dan alih teknologi

1). Teknologi dan alih teknologi menurut PBB

Mengacu pada rekomendasi konferensi Vienna tahun 1979, General Assembly (Majelis Umum) membentuk komite antarpemerintah dalam bidang IImu Pengetahuan dan Teknologi, terbuka untuk semua negara untuk membuat guidline/panduan kebijakan, memonitor aktivitas dalam sistem PBB, mempromosikan penerapan program Vienna, mengidentifikasi prioritas-prioritas dan memobilisasi sumber-sumber. The general assembly juga membentuk sekretariat pusat IImu Pengetahuan dan Teknologi untuk pembangunan dalam rangka membantu negara-negara berkembang menentukan isu-isu IImu Pengetahuan dan Teknologi dan pilihanpilihan untuk pembangunan ; untuk membantu mereka merespon tawaran peluang-peluang dari ilmu pengetahuan dan teknologi baru dan mendadak tersebut yang paling tepat untuk pembangunan negara yang bersangkutan ; untuk mempromosikan IImu Pengetahuan asli dan kemampuan teknologi untuk negara-negara berkembang. ; dan untuk menyelaraskan capaian pembangunan dari sistem PBB dan badan-badan khususnya dalam bidang ilmu pengetahuan dan teknologi untuk pembangunan.

2). Teknologi dan alih teknologi menurut TRIPs Agreement

Filosofi mendasar tentang pengaturan alih teknologi dalam TRIPS Agreement adalah karena teknologi memiliki kaitan yang sangat kuat dengan beberapa kekayaan intelektual seperti paten dan merek. 
Alih teknologi dalam persetujuan tersebut diatur dalam pasal 7 dan pasal 8.

Oleh karena itu, terdapat alasan moral dan sosial sebagaimana tercantum dalam kedua pasal tersebut yang menyebutkan ;

\section{Article 7 \\ Objectives}

"The protection of enforcement of intellectual property rights should contribute to promotion of technological innovation and to the transfer and dessimation of technology to the mutual advantages of producers and users of technological knowledge in a manner conductive to social and economic welfare, and to balance of rights and obligations."

e. Pengaturan alih teknologi dalam hukum positif Indonesia

1). Undang-undang No. 1 tahun 1967

Keberadaan teknologi dalam undang-undang tersebut secara tegas diatur dalam pasal 2, yang menyebutkan bahwa pengertian modal asing dalam undang-undang ini adalah :

(a). Alat pembayaran luar negeri yang tidak merupakan bagian dari kekayaan devisa Indonesia, yang dengan persetujuan pemerintah digunakan untuk pembiyaan perusahaan di Indonesia

(b). Alat-alat untuk perusahaan, termasuk penemuan-penemuan dari milik orang asing dan bahan-bahan yang dimasukkan dari luar ke dalam wilayah Indonesia, selama alat-alat tersebut tidak dibiayai dari kekayaan devisa Indonesia.

2). Undang-undang No. 6 tahun 1967

Undang-undang No. 6 tahun 1967 tentang Penanaman Modal Dalam Negeri secara jelas mengatur tentang alih teknologi yang terjadi dengan cara importasi barang-barang modal termasuk alat-alat 
dan perlengkapan perusahaan. Secara lengkap diatur dalam pasal 15 :'...pengimporan barang-barang modal, termasuk peralatan dan perlengkapan perusahaan yang diperlukan untuk usaha-usaha pembangunan baru dan rehabilitasi dalam bidang-bidang tersebut dalam pasal 9 ayat (1) dapat diberi keringanan-keringan bea masuk".

3). Undang-undang No. 25 tahun 2007

Undang-undang No. 25 tahun 2007 menyebutkan secara letter lijk tentang pengaturan alih teknplogi sebagaimana diatur dalam pasal 3 ayat (2) huruf c, bahwa salah satu tujuan penyelenggaraan penanaman modal adalah meningkatkan kapasitas dan kemampuan teknologi nasional. Pasal 10 ayat (4), dalam hal ketenagakerjaan jika penanaman modal mempekerjakan tenaga kerja asing, maka penanam modal tersebut diwajibkan untuk menyelenggarakan pelatihan dan melakukan alih teknologi kepada tenaga kerja warga negara Indonesia sesuai dengan ketentuan peraturan perundangundangan. Pasal 12 ayat (5) tentang bidang usaha, pemerintah menetapkan bidang usaha yang salah satu tujuannya adalah untuk meningkatkan kapasitas teknologi nasional.

4). Undang-undang No. 4 tahun 1984

Disamping berbagai peraturan perundang-undangan diatas, Undang-undang no. 4 tahun 1984, terutama pasal 16 ayat (2) tentang Perindustrian memberi peluang alih teknologi ke dalam negeri jika perangkat teknologi industri yang dibutuhkan tidak cukup tersedia di dalam negeri.

5). Undang-undang No. 14 tahun 2001

Dua hal penting berkaitan dengan alih teknologi sebagaimana diatur dalam Undang-undang No. 14 tahun 2001 tentang Paten. Undang-undang tersebut mengatur dua hal : Pertama, cara beralihnya teknologi (tehnologi yang dipatenkan) bisa melalui beberapa cara sebagaimana diatur dalam pasal 66, bahwa paten dapat beralih atau dialihkan, baik sebagian atau seluruhnya karena 
pewarisan, hibah, wasiat, perjanjian tertulis ataupun sebab lain yang dibenarkan oleh peraturan perundang-undangan. Kedua, larangan pencantuman klausul restriktif dalam kontrak lisensi sebagaimana diatur dalam pasal 71 disebutkan bahwa klausul perjanjian lisensi tidak boleh memuat ketentuan, baik langsung maupun tidak langsung, yang dapat merugikan perekonomian Indonesia dan mengembangkan teknologi pada umumnya.

6). Undang-undang No. 18 tahun 2002 dan Peraturan Pemerintah No. 20 tahun 2005

Undang-undang No. 18 tahun 2002 dan Peraturan Pemerintah No. 20 tahun 2005 merupakan satu paket yuridis yang mengatur tentang teknologi dan alih teknologi yang terkait langsung dengan kegiatan penelitian dan pengembangan secara nasional.

7). Keputusan Menteri Perindustrian No. 41/M/SK/3/1979

Surat Keputusan (SK) Menperin No. 41 tahun 1979 mengatur secara khusus alih teknologi dalam kegiatan industri tekstil. SK Menperin tersebut menyebut secara eksplisit tentang cara peralihan teknologi yang bisa dilakukan melalui penyuluhan, seminar, penataran, pendidikan, dan latihan.

\section{Metode Penelitian}

Penelitian ini merupakan penelitian hukum empiris dan merupakan penelitian kualitatif. Sumber data yang digunakan adalah data primer sebagai data utama serta data sekunder sebagai data pendukung. Lokasi penelitian ini adalah PT. Primatexco Indonesia di Kabupaten Batang Jawa Tengah. 


\section{B. HASIL PENELITIAN DAN PEMBAHASAN}

\section{Pelaksanaan Alih Teknologi}

\section{a. Peralihan Technical Know-How}

Pada prinsipnya, alih teknologi yang berkaitan dengan technical knowhow diuraikan menjadi dua era $;^{10}$

1). Era 1971-1990

Transfer of Technical know-how pada era tersebut dilakukan dengan cara sit in, artinya para operator mesin serta para pejabat dari pihak PT. Primatexco Indonesia diberangkatkan ke Daiwabo's Maizuru Mills, Kota Kyoto untuk mempelajari secara langsung mesin-mesin (khusus cara mengoperasikan semua mesin produksi) yang akan digunakan dalam proses produksi di PT. Primatexco Indonesia. Pelatihan tersebut dipandu oleh beberapa orang teknisi yang sudah disiapkan oleh Daiwabo Corporation.

Tujuan dilkutsertakannya para pejabat di PT. Primatexco Indonesia dalam proses pelatihan tersebut adalah agar mereka memahami tentang cara mengoperasikan serta merawat mesin-mesin, meski dalam pekerjaan sehari-hari tidak bersangkutan langsung dengan bidang tersebut. Mesin-mesin di Daiwabo's Maizuru Mills tidak akan dikirimkan ke Indonesia sebelum para operator mesin serta para pejabat belum bisa memahami bagaimana cara mengoperasikan mesin secara benar sesuai dengan panduan para technician dari Jepang.

\footnotetext{
${ }^{10}$ Hasil wawancara dengan Kepala Unit Purchasing dan Warehouse PT. Primatexco Indonesia H.Nanggolo Mulyo Waniaji, pada tanggal 25 Maret 2009
} 
Disamping model Sit In, pada era 1971-1990 juga sudah diberlakukan peralihan know-how dalam bidang maintenance dengan cara pengiriman maker ${ }^{11}$ dari Daiwabo ke Indonesia untuk memberikan pelatihan tentang cara merawat mesin. Model alih teknologi era ini merupakan domain kewajiban Daiawbo Corporation.

Pengiriman tenaga/operator Indonesia ke Jepang yang sudah berlangsung sejak tahun 1971 hingga sekarang, pada hakekatnya telah terjadi alih teknologi di PT. Primatexco Indonesia sejak tahun 1980-an.

2). Era tahun 1990 hingga sekarang

Alih teknologi dalam bidang technical know-how pada era 1990 sampai sekarang dilakukan di PT. Primatexco Indonesia. berkebalikan dengan cara sebelumnya dimana pihak Indonesia berbondongbondong ke Jepang, pada era 90, para ahli/teknisi dari Jepang bersama mesin didatangkan ke Indonesia. Pembelian mesin-mesin dilakukan melalui mekanisme importasi biasa. Keseluruhan proses produksi (spinning, weaving, finishing), PT. Primatexco Indonesia ditopang oleh 25 jenis mesin yang terdiri dari unit spinning (pemintalan) sebanyak 11 mesin, unit weaving (penenunan) sebanyak 4 mesin, dan unit finishing (penyempurnaan) sebanyak 10 mesin. Semua mesin beserta sparepartnya harus didatangkan dari Jepang. Pihak yang bertanggung jawab atas pengadaan mesin dan suku cadang tersebut adalah Sojitz Corporation.

Menurut Erman Raja Gukguk ${ }^{12}$, alih teknologi dalam kerangka PMA terjadi melalui dua cara, yakni alih teknologi dalam penyerapan teknologi dan alih teknologi dalam pengertian mewarisi perusahaannya karena habis ijin usahanya, karena perjanjian, kompensasi atau nasionalisasi dalam arti dijalankan sepenuhnya, baik tenaga ahli maupun modal oleh pihak nasional.

\footnotetext{
${ }_{11}^{11}$ Maker adalah istlah untuk orang yang ahli dalam bidang mesin-mesin tertentu.

${ }^{12}$ Erman Raja Gukguk, Hukum Investasi (Jakarta : RajaGrafindo Persada), hal.512
} 
Menurut Maskus, dalam kegiatan alih teknologi penerima teknologi harus mampu mengakses know-how dari korporasi lain untuk mempelajarinya dengan sukses dan kemudian menyerapnya dan menerapkannya dalam proses produksi di perusahaannya. Analisis Keith E. Maskus dalam hal alih teknologi sudah secara spesifik membidik bidang industri, yakni berupa akses informasi teknis perusahaan pemilik teknologi untuk diterapkan dalam proses produksi di perusahananya. Menurut peneliti, proses alih teknologi di PT. Primatexco Indonesia berdasarkan pada pendapat Maskus dimana alih teknologi dalam bentuk importasi mesin tidak berarti telah terjadi alih know-how sehingga meskipun proses produksi yang berlangsung di perusahaan tersebut menggunakan mesin-mesin, tetapi mesinmesin tersebut bukan hasil dari kreasi sendiri.

Berdasarkan analisis tersebut yang didasarkan dari beragam pendapat tentang bagaimana seharusnya alih teknologi itu terjadi, maka di PT. Primatexco Indonesia yang proses produksinya sangat padat teknologi, belum terjadi proses alih teknologi dalam arti yang susungguhnya yang sempurna dan utuh, akan tetapi baru terjadi alih pengetahuan kecaraan (transfer of know-how) tentang alat, baik pengetahuan pengoperasiannya maupun pengetahuan tentang perawatan/pemeliharaannya. Proses transfer of knowledge hanya digunakan sebagai dalih oleh pihak asing untuk menggunakan fasilitas joint venture demi kepentingan bisnis pihak asing semata. Standarisasi kualitas produk dan proses produksi serta proses manajemen dilaksanakan dalam rangka merebut pasar internasional karena sebagian besar produk PT. Primatexco Indonesia dipasarkan dengan mekanisme ekspor ke berbagai negara.

\section{b. Peralihan Know How of Manufacturing/management}

Kagiatan investasi langsung oleh Jepang di Indonesia berbeda dengan negara-negara yang lain. Training dalam bidang manjemen dalam rangka kerjasama usaha patungan pada umumnya dibuat kontrak atau 
perjanjian dalam bentuk Management Contract yang merupakan breakdown atau pengkhususan dari pasal-asal yang diatur dalam Basic Agreement of Joint Venture. Namun, khusus untuk investor Jepang pelatihan/training di bidang majemen, baik manajemen sumber daya manusia atau aspek manajemen yang lain, tidak hanya didasarkan atas agreement para pihak yang bersangkutan langsung seperti PT. Primatexco Indonesia-Daiwabo, akan tetapi dikelola oleh pihak ketiga (the third party), dalam hal ini organisasi profesi (Personal Manager Agency) yang membidangi hal tersebut.

Organisasi profesi manajemen, khususnya managemen sumber daya manusia (SDM) untuk tingkat Asia bernama AOTS (The Asosiation for Overseas Technical Scholarship). AOTS bekerjasama dengan NICC (Nippon-Keidanren International Corporation), semacam Apindo di Indonesia. Di dalam struktur kelembagaan NICC terdapat bidang yang khusus menangani training manajemen SDM khusus berlaku untuk 9 negara-negara Asia yaitu ; Indonesia, Mongolia, Thailand, Camboja, China, Malaysia, Philipina, Laos serta Vietnam. ${ }^{13}$ Peserta yang diberangkatkan ke Jepang didasarkan atas seleksi dan dibatasi 15 peserta untuk 9 negara dalam jangka waktu 8 bulan. Kedudukan perusahaan yang memberangkatkan hanya sebatas pemberi rekomendasi atas personal manager yang diberangkatkan.

Menurut Keith E Maskus, alih teknologi yang terjadi dalam perusahaan patungan memiliki karakter yang khas dan beralih tanpa hambatan. Bahkan alih teknologi itu sendiri merupakan orientasi dari pihak asing sebagai salah satu ukuran jaminan kualitas produksi yang memiliki standar secara internasional. Pengalihan pengetahuan tentang proses produksi dan proses manajemen merupakan bagian yang tak terpisahkan dari kegiatan alih teknologi itu sendiri."...Further, knowledge about production and management processes may be gained from reverse engineering, reading published materials, training within firms and

\footnotetext{
${ }^{13}$ NICC-APMPT, Outline of The Training Program, (Japan :NICC, tanpa tahun), hal. 2
} 
laboratories, and attending professional conferences. Finally, much information may be in the public domain." ${ }^{14}$ Pengetahuan tentang produksi dan manajemen tersebut sudah menjadi domain publik dan tidak lagi mendapatkan perlindungan secara eksklusif serta tidak lagi menjadi pemegang monopoli atas kepemilikan hak-hak intelektualnya. Sebab, dibalik niat baik untuk mengalihkan pengetahuan tentang proses produksi dan proses manajemen secara bebas, pihak asing telah memperlakukan pihak nasional sebagai alat/sarana untuk mencapai kepentingannya, dalam hal ini keuntungan yang diperoleh dari kegiatan perdagangan.

C. Hambatan-hambatan yang dihadapi dalam alih teknologi

a. Hambatan Yuridis

Proses alih teknologi pada perusahaan joint venture pada umumnya dan pada PT. Primatexco Indonesia secara khusus, menghadapi hambatan yang bersifat yuridis, yakni karena teknologi merupakan bagian dari keseluruhan modal, sehingga proses peralihannya, hak dan kewajibannya menjadi kabur karena alih teknologi tidak diatur secara spesifik dalam kontrak alih teknologi dan tidak termasuk salah satu klausul dalam kontrak joint venture. Teknologi sebagai unsur modal sebagaimana diatur dalam UU PMA menyebabkan penentuan pilihan teknologi dilakukan secara sepihak, yakni pihak pemilik teknologi.

b. Hambatan Non Yuridis

(1). Hambatan dalam pelaksanaan Alih Teknologi yang bersifat teknis

Secara umum, selama proses pelaksanaan alih teknologi maupun proses training, terdapat dua jenis hambatan, yakni ia. hambatan teknis dan hambatan non teknis. Adapun hambatan teknis adalah hambatan yang berpengaruh langsung terhadap proses alih teknologi dalam hal ini adalah sistem bahasa. Pada prinsipnya, buku panduan,

\footnotetext{
${ }^{14}$ http://www.ipsoline.org/unctad/bellagio/docs/Maskus, Transfer of Technology and Technological Capacity Building, diakses pada tanggal 23 Februari 2009
} 
baik yang berupa guiding book of machine operating ${ }^{15}$ maupun guiding book of machine maintenance ${ }^{16}$ menggunakan bahasa Inggris dan masih bisa dikuasai oleh calon operator mesin karena dilengkapi dengan bagan dan gambar. Sedangkan hambatan teknis yang sangat terasa adalah pemakaian bahasa Jepang yang sangat sulit untuk dipelajari dan dipahami, disamping karena model huruf, tulisan serta cara pengucapan yang sangat berbeda dengan bahasa Indonesia.

(2). Hambatan dalam pelaksanaan Alih Teknologi yang bersifat Non Teknis

Meskipun perusahaan PT. Primatexco Indonesia sudah menjalankan kegiatan usaha selama sekitar 36 tahun, namun dilihat dari aktivitas manajemen produksi, perusahaan tersebut sampai sekarang tetap masih berada di fase yang pertama dan tidak berusaha melakukan peningkatan pada fase alih teknologi yang lebih tinggi.

Disamping karena faktor kultural, yakni sikap para pegawai di jajaran managemen maupun para karyawan bidang produksi yang hanya memposisikan diri sebagai pekerja semata, juga karena faktor non kultural seperti lemahnya pemahaman mereka tentang hukum, baik hukum penanaman modal, joint venture maupun secara khusus hukum alih teknologi.

D. Upaya-upaya untuk Mengatasi Hambatan dalam Pelaksanaan Alih Teknologi

a. Hambatan Yuridis

PT.Primatexco Indonesia dan juga PT-PT yang lain hasil joint venture tidak bisa mengatasi hambatan yuridis yang dihadapinya secara langsung. Pada prinsipnya, pengaturan yuridis alih teknologi menjadi

\footnotetext{
${ }^{15}$ Buku petunjuk/manual yang berisi informasi mendetail tentang informasi tentang bagaimana mengoperasikan suatu mesin produksi. Meski ditulis dalam bahasa Inggris, para operator tidak mengalami kesulitan karena dalam buku tersebut juga dilengkapi dengan bagan dan gambar sehingga mempermudah pemahaman teknis.

${ }^{16}$ Buku petunjuk/manual yang berisi informasi mendetail tentang cara perawatan mesin.
} 
sumber utama stagnasi Perseroan Terbatas yang bersifat joint venture. Oleh karena itu, PT. Primatexco Indonesia memiliki kepentingan untuk mengatasi hambatan, namun dengan cara tidak langsung. Cara yang dilakukan adalah secara proaktif memberikan masukan kepada pemerintah atas hambatan-hambatan yuridis yang dihadapinya melalui mekanisme yang ada.

Adapun mekanisme yang selama ini berlangsung adalah melalui Rapat Umum Pemegang Saham (RUPS). Sebab media RUPS lah yang mempertemukan pihak manajemen dengan para pemegang saham, terutama sekali adalah pemegang saham minoritas.

Atas kebuntuan jalan tersebut, sesuai dengan hasil studi lapangan penelitian tesis ini, PT. Primatexco Indonesia mengambil upaya untuk mengatasi permasalahan yuridis dimaksud dengan cara melakukan benchmarking terhadap perusahaan sejenis. Benchmarking atau patok duga tersebut dilakukan terhadap industri tekstil PT. APAC INTI Corpora ( PMDN) di Bawen, PT. Batam Tex ( PMA-Indonesia-Korea) dan beberapa perusahaan lain, semuanya sudah menggunakan teknologi tekstil yang lebih modern. Kegiatan benchmarking tersebut ternyata terbukti berhasil meminimalisir kesenjangan teknologi tekstil antara Jepang dengan Indonesia.

b. Hambatan non Yuridis

(1). Hambatan yang bersifat teknis

Upaya untuk mengatasi hambatan teknis dilakukan dengan cara mengadakan pelatihan bahasa Jepang yang dilaksanakan di Maizuru (Daiwabo Corporation). Pelatihan bahasa dilakukan dengan cara berinteraksi langsung dengan native speaker ${ }^{17} \mathrm{di}$

\footnotetext{
${ }^{17}$ Penutur asli bahasa Jepang.
} 
Jepang. Peningkatan kemampuan dalam menggunakan bahasa Jepang sebagai bahasa percakapan sangat berguna saat berkomunikasi dengan managemen asing (Jepang) yang seharihari berkantor di PT. Primatexco Indonesia dan menetap di Indoensia. Sebenarnya banyak sekali keunggulan dari kemampuan berkomunikasi dengan bahasa Jepang, salah satunya adalah berdiskusi tentang keadaan perusahaan diselasela pekerjaan.

Disamping menyelenggarakan pelatihan bahasa Jepang, hambatan teknis lainnya dilakukan dengan cara mempererat kerjasama dengan perusahaan penyelenggara pelatihan kemanufakturan, baik yang bersifat nasional maupun internasional. Kerjasama nasional dilakukan dengan Departemen Tenaga Kerja (Depnaker) dengan cara mengirimkan nominasi untuk terlibat dalam pengiriman pelatihan pekerja ke Jepang. Sedangkan kerjasama internasional (tingkat Asia) dilakukan dengan organisasi pelatihan manajemen (AOTS).

Kerjasama-kerjasama yang dilakukan oleh PT. Primatexco Indonesia, baik tingkat nasional maupun tingkat internasional merupakan salah satu cara untuk mengatasi permasalahan yang sangat teknis dan berpengaruh terhadap kegiatan perusahaan.

(2). Hambatan yang bersifat non teknis

Hambatan yang bersifat non teknis diatasi dengan cara terus memperkuat relasi bisnis/relasi yang bersifat korporasional dengan perusahaan-perusahaan afiliasi GKBI, seperti PT. Tokai Texprint Indonesia, PT. Dayani, dan PT. Pintex. Disamping membangun pasar dalam negeri, afiliasi tersebut juga dimaksudkan untuk membagi pekerjaan sehingga produksi di perusahaan-perusahaan afiliasi tersebut tersentuh dengan teknologi yang lebih baru. Penguatan relasi ini juga dimaksudkan 
untuk mengakses teknologi yang baru yang sama sekali belum di kenal di PT. Primatexco Indonesia.

\section{E. PENUTUP}

1. Kesimpulan

a. Pelaksanaan alih teknologi di PT. Primatexco Indonesia dilakukan melalui dua cara, yaitu dengan cara sit in dan dengan cara importasi mesin disertai pengiriman tenaga ahli ("maker") serta dilengkapi dengan guiding book of operating machianery dan guiding book of maintenance machianery.

b. Hambatan dalam Pelaksanaan Alih Teknologi

Hambatan yuridis berupa adanya beberapa klausul pembatasan seperti kewajiban penggunaan teknologi melalui Sojitz Corporation. Hambatan non yuridis berupa permasalahan bahasa campuran Jepang-Inggris dalam proses alih teknologi serta kultur lingkungan PT. Primatexco berposisi tidak turut menentukan arah perusahaan.

c. Upaya untuk Mengatasi Hambatan dalam Pelaksanaan Alih Teknologi

Hambatan yuridis diatasi dengan cara mendorong pemerintah untuk mengendalikan praktik-praktik kontrak yang melibatkan pihak asing (misalnya terhadap kemungkinan-kemungkinan lahirnya klausul-klausul restriktif) melalui peraturan perundang-undangan yang jelas dan tidak menimbulkan tafsir ganda.

Hambatan non yuridis diatasi dengan memperkuat hubungan dengan perusahaan afiliasi yang memungkinkan akses teknologi baru dalam bidang tekstil 
2. Saran

a. Semua jajaran dalam perusahaan Joint Venture dalam hal ini pihak nasional hendaknya turut secara aktif dan kritis turut merumuskan arah perusahaan sehingga kontrak-kontrak yang disusun, terutama bidang alih teknologi, menampung kepentingan para pihak secara berimbang dan adil tanpa ada unsure dominatif.

b. Semua perusahaan Joint Venture (pihak nasional) hendaknya mengadakan kerjasama sehingga mampu memberikan daya tawar yang kuat, baik terhadap pemerintah maupun terhadap perusahaan asal negara lain.

3. Rekomendasi

Berdasarkan hasil penelitian dilapangan, terdapat beberapa permasalahan yuridis yang tidak mungkin diatasi oleh pihak PT. Primatexco Indonesia, yakni peluang terhadap kemungkinan aksi divestasi besar-besaran oleh pihak asing yang akan berdampak langsung pada peninggalan teknologi obsolete pihak nasional.

Disamping itu, tidak jelasnya pengaturan kontrak joint venture yang didasari atas kebebasan para pihak tanpa ada sedikitpun campur tangan pemerintah dalam bentuk restriksi klausul menyebabkan praktek terselubung atas pengendalian teknologi usang oleh pihak asing. Berdasarkan paparan tersebut, peneliti merekomendasikan dua hal sebagai berukut :

a. Pemerintah hendaknya segera membuat Undang-undang khusus tentang Alih Teknologi yang antara lain memuat kewajiban pihak asing sebelum melakukan aksi divestasi besar-besaran terhaap perusahaan joint venture yang didirikannya.

b. Pemerintah juga harus segera menambahkan/memperbaharui ketentuan kontrak/perjanjian yang sudah ada yang berupa ketentuan klausul restriktif dalam rangka melindungi perusahaan nasional seperti yang dilakukan oleh beberapa negara Asia lainnya. 


\section{DAFTAR KEPUSTAKAAN}

Adolf, Huala, Dasar-dasar Hukum Kontrak Internasional, Cetakan kedua (Bandung : Refika Aditama, 2008)

Amalia, Lia, Ekonomi Internasional, , Edisi Pertama, Cetakan Pertama ( Jakarta : Graha Ilmu, 2007 )

Ashshofa, Burhan, Metode Penelitian Hukum, Cetakan Ketiga (Jakarta : PT. Rineka Cipta, 2001) 
Hartono, C.F.G. Sunaryati, Penelitian Hukum pada Akhir Abad ke-20, Cetakan ke-1 ( Bandung : PT. Alumni, 1994 )

H. Weston, Burns, et all, Basic Document in International Law and World Order, American Casebook Series, Second Edition ( St. Paul Minn : West Publishing CO, 1990 )

J.Ravianto (alih bahasa), Alih Teknologi Intra-Nasional (Jakarta : LSIP, 1987)

Ilmar, Aminuddin, Hukum Penanaman Modal di Indonesia ( Jakarta : Kencana, 2004 )

Keraf, Gorrys, Komposisi, Cetakan XII (Flores : Nusa Indah, 2001)

Lubis, Todung Mulya, Hukum dan Ekonomi, Cetakan Pertama ( Jakarta : Pustaka Sinar Harapan, 1987 )

M. Friedman, Lawrence, The Legal System : A Social Science Prespective (New York : Russel Sage Foundation,1975)

Mochtar, Dewi Astuti, Perjanjian Lisensi Alih Teknologi dalam Pengembangan Teknologi di Indonesia, Edisi 1 Cetakan Pertama ( Bandung: Alumni, 2002 )

Noori, Hamid, Managing the Dynamic of New Technology ( New Jersey : Prentice Hall, tanpa tahun)

Notosusanto, Nugroho, Sejarah Nasional Indonesia 3, (Jakarta : Dinas Pendidikan dan Kebudayaan, 1991)

Pamuntjak, Amir, Sistem Paten : Panduan Praktik dan Alih Teknologi ( Jakarta : Djambatan, 1994 )

Purwaningsih, Endang, Perkembangan Hukum Intelectual Property Rights : Kajian Hukum terhadap Hak atas Kekayaan Intelektual dan Kajian Komparatif Hukum Paten, Cetakan I ( Bogor : Ghalia Indonesia, 2005 )

Raja Gukguk, Erman, Hukum Investasi (Jakarta : PT.RajaGrafindo, 2001)

Raharjo, Agus, Hukum dan Teknologi : Suatu Tinjauan Filosofis dan Kritik Terhadap Positivisme Hukum ( Semarang : Penerbit Universitas Diponegoro, 2007 )

Rahardjo, Satjipto, IImu Hukum, Cetakan keenam ( Bandung : Citra Aditya Bakti, 2006 ) 
Rene Dubos, et all, Harta Karun Teknologi dalam ILMUWAN ( Jakarta : Tira Pustaka , 1980 )

Ridwan, Juniarso, Manusia Teknologi Mitos dan Realitas, Cetakan ke1(Bandung:Angkasa, 1982)

Salim HS, dkk, Perancangan Kontrak dan Memoranum of Understanding, Cetakan ketiga (Jakarta : Sinar Grafika, 2008)

Sembiring, Sentosa, Hukum Investasi, Cetakan kesatu (Bandung: Nuansa Aulia, 2007)

, Hak Kekayaan Intelektual dalam Berbagai Peraturan Perundang-undangan, Cetakan ke-1 (Bandung : Yrama Widya, 2002)

Soekanto, Soerjono, Pengantar Penelitian Hukum, Cetakan ke-3 ( Jakarta : Penerbit Universitas Indonesia ( UI-Press ), 1986 )

Soekanto, Soerjono dan Sri Mamuji, Pengantar Metode Penelitian Hukum Normatif (Jakarta : PT. RajaGrafindo, 2004)

Soemitro, Ronny Hanitijo, Metodologi Penelitian Hukum dan Jurimetri, Cetakan ke-4 ( Jakarta : Ghalia Indonesia, 1994 )

S.Nasution, Metode Research, Edisi 1 Cetakan ke-4 ( Jakarta : Bumi Aksara, 2001) Subekti, Hukum Perjanjian, Cetakan VI ( Jakarta : Intermasa, 1979)

Soemitro, Rochmat, Pengantar Ekonomi dan Ekonomi Pancasila, Cetakan VIII(Jakarta-Bandung : Eresco, 1983)

Sumantoro, Hukum Ekonomi( Jakarta : Penerbit Universitas Indonesia ( UI-Press ), 1986 )

------------, Masalah Pengaturan Alih Teknologi, Cetakan I ( Bandung : Alumni, 1982 )

Susilowati, Etty, Kontrak Alih Teknologi pada Industri Manufaktur, Cetakan Pertama ( Yogyakarta : Genta Press, 2007 )

Tuti MG, dkk, Tata Negara, Cetakan 1(Bandung : Angkasa, 1988)

Widjaya, Gunawan, LISENSI, Edisi 1, Cetakan 1 ( Jakarta : PT. RajaGrafindo Persada, 2001)

Winardi, Pengantar Tentang Teori Sistem dan Analisis Sistem, Cetakan kedua

(Bandung : PT. Alumni, 1986) 
YB. Mangunwijaya (Editor), Teknologi dan Dampak Kebudayaannya, Volume 1 ( Jakarta : Yayasan Obor Indonesia bekerjasama dengan AUSAID, 1983 )

\section{PERATURAN PERUNDANG-UNDANGAN}

R.Subekti dan R.Tjitrosudibio, Kitab Undang-Undang Hukum Perdata, Edisi Revisi, Cetakan ketigapuluh (Jakarta : Pradnya Paramita, 1999)

Undang-undang No. 1 tahun 1967 tentang Penanaman Modal Asing

Undang-undang No. 6 tahun 1968 tentang Penanaman Modal Dalam Negeri

Undang-undang No. 4 tahun 1984 tentang Perindustrian

Undang-undang No. 24 tahun 1999 tentang Lalu Lintas Devisa

Undang-undang No. 14 tahun 2001 tentang Paten

Undang-undang No. 18 tahun 2002 tentang Sistem Penelitian Perguruan Tinggi

Peraturan Pemerintah No. 20 Tahun 2005 tentang Alih Teknologi Kekayaan

Intelektual Serta Hasil Kegiatan Penelitian dan Pengembangan Oleh Perguruan

Tinggi dan Lembaga Penelitian dan Pengembangan

Undang-undang No. 25 tahun 2007 tentang Penanaman Modal.

Surat Keputusan Menteri Perindustrian No.41/M/SK/3/1979, Susunan Organisasi

dan Tata Kerja Balai Penelitian dan Pengembangan Industri Tekstil

\section{Kamus dan Makalah :}

Normin S. Pakpahan, dkk, Kamus Hukum Ekonomi, Edisi Pertama Cetakan kedua (Jakarta : Ellips, 1997)

Peter Salim, Advanced English-Indonesia, Cetakan kelima (Jakarta : Modern

English Press, 2001)

Newsletter, Hukum dan Perkembangannya, Edisi September No. 7 tahun 2007

\section{Sumber Internet}

www.apru.co.id

www.sinar harapan.co.if

http : //en-wikipedia.org/wiki/the history of technology

http : //en-wikipedia.org/wiki/multinational corporation

www.ristek.go.id 
http://www-rohan.sds2.edu/faculty/feenberg.CRITISAM 2.HTML, The theory of

Technology, diakses pada tanggal 9 Februari 2009

http://www.project2061.org/publication/sfaa/online/chap3.htm, the nature of technology, diakses pada tanggal 24 Februari 2009

http://www.unctad.co.id, Policies and programmes for technology development and mastery, including the role of FDI, diakses pada tanggal 24 Februari 2009 http://zulkieflimansyah.com/in/sejarah panjang industri nasional, diakses pada tanggal 20 Maret 2009 http://egypsi.woedpress.com, Industri tekstil dan Produksi Tekstil Indonesia, diakses pada tanggal 20 Maret 2009 http:www.deddy24.trustpass.alibaba.com, Digitized Company Profile of Primatexco Indonesia PT, diakses pada tanggal 21 Maret 2009 http://contracts.onede.com, OEM Manufacturing Contract, diakses pada tanggal 21 Maret 2009 , Technology Transfer Agreement, diakses pada tanggal

21 Maret 2009

www.primtexcoindonesia.com, diakses pada tanggal 21 Maret 2009 http://www.allbusiness.com/manufacturing/textiles, Primatexco : Progressing Shift to AJL, diakses pada tanggal 21 Maret 2009 , Daiwabo Group, diakses pada

tanggal 21 Maret 2009

http://en.wikipedia.org/wiki, Joint Venture, diakses pada tanggal 21 Maret 2009 http://en.wikipedia.org/wiki, Company Profile Sojitz Corporation, diakses pada tanggal 21 Maret 2009 